\title{
Effects of nutrition plane on productive performances of Ossimi ewes and their offspring during pregnancy and lactation periods
}

\author{
Lashein M. E. ${ }^{\mathrm{a}}$, Abd-Allah M. ${ }^{{ }^{*}}$, Hussein A. M. A. ${ }^{\mathrm{c}}$, Tawfik M. H. $^{\mathrm{b}}$ \\ ${ }^{a}$ Department of Animal Production, Faculty of Agriculture, Al-Azhar, University, Cairo, Egypt \\ ${ }^{b}$ Department of Animal Production, Faculty of Agriculture, Al-Azhar University, Assiut 71524, Egypt \\ ${ }^{c}$ Department of Animal Production, Faculty of Agriculture, Assiut University, Egypt
}

\begin{abstract}
Feeding ewes diets with higher energy and crud protein during gestation and lactation affects the performance of lambs at weaning. The objective of this study was to determine the nutrition plane supplementation during pregnancy and lactation period affects ewes and their offspring performance. from birth to weaning. Twenty four Ossimi ewes with average weight $55.67 \mathrm{~kg}$ and aged 2-4 years old and their offspring $(\mathrm{n}=30)$ were used in completely randomized design consisting of three supplementation level (high,125\%ME; standrd,100\% ME and low, 60\% ME) of predicated metabolizable energy requirements according to NRC, 1985. The ewes were weighted and the body weights of lambs were recorded from birth to weaning. Colostrum production was recorded during the first week after parturition, the amount of milk production was estimated after that weekly until weaning. Blood samples were also collected from the ewes and analyzed to determine blood components. There was no effect of nutrition plane on live body weight of ewes during pregnancy and lactation period. Ewes were had significantly $(P \leq 0.01)$ higher colostrum and milk yield compared with ewes offered medium ME or low group. The values of TMY, ADMY and colostrum yield were significantly $(P \leq 0.01)$ higher in ewes fed high ME diet compared with ewes fed on medium or low ME diet. All blood constituents were not affected by nutrition plane during pregnancy except for cholesterol and glucose levels were affected significantly $(P \leq 0.05)$, Likewise, during the lactation period, with the exception of cholesterol levels, which were significantly $(P \leq 0.05)$ affected. There was a significant $(P \leq 0.05$ or $P \leq 0.01)$ increase in body weight and daily gain for lambs resulting from ewes offered high ME diet compared ewes offered medium ME or low ME diet. In conclusion it can be said that, nutrition plane is every important of ewes during pregnancy and lactation period and feeding the ewes at high ME can improve the performance of growth and milk production without any negative effect on the blood components.
\end{abstract}

Keywords: nutrition plane, growth performance, blood constituents, colostrum, milk yield. 


\section{Introduction}

Due to high nutritional requirements for colostrum and milk production, parturition and lactation considered is the most critical and stressful period of the rams life cycle because energy is the greatest requirement of animals, and energy used by the animal is derived chiefly from energy ingested and secondly from the mobilization and catabolism of bodily reserves (MorandFehr and Doreau, 2001). The plane of nutrition available to the ewes during gestation has been shown to positively influence both udder development and subsequent lactation performance (Blair et al., 2010), also the ability of the dam to produce milk for her offspring is a key driver of neonatal growth and development (Morgan et al., 2007). Optimal maternal nutrition and subsequent fetal growth, as precursors of efficiency, are therefore critical in determining the profitability of meat and lamb production enterprises (Redmer et al., 2004). A Nutritional status of the ewe during pregnancy is critical, as it has major implications through its effect on ewe reproductive efficiency and colostrum production, and also, on fetal development and subsequent lamb survival and performance. Nutrition influences certain metabolic pathways, not only directly by providing essential nutrients, but also, indirectly by modifying the expression of hormonal functions, which in turn influence oocyte maturation, ovulation, embryo development, fetal growth and the viability and vigor of the newborn lamb (Robinson, 2002). Generally, dietary restrictions in only one stage of pregnancy do not affect plasma concentrations of total protein but the latter was significantly correlated with birth weight (Addah and Karikari, 2008). Lamb survival is related to the nutrition of the ewe during late gestation (Binns et al., 2002). Lamb growth to weaning and survival is influenced by a number of factors including ewe nutrition during both pregnancy (Behrendt et al., 2011; Greenwood et al., 2010) and lactation (Coop et al. 1972). In sheep, maternal nutrition can affect production traits such as the offspring's milk production and the grand offspring's live weight to weaning (Kenyon et al., 2014). This study aimed to evaluate the effect of nutrition planes supplementation in the mid and latepregnancy and during lactation period on the change in live body weight, milk production and same blood constituents of Ossimi ewes and their offspring.

\section{Materials and methods}

The present study was conducted during the period from October 2017 to August 2018 at the experimental farm of Animal Production Department, Faculty of Agriculture, Al-Azhar University, Assiut Branch, Assiut, Egypt. In order to determine the effects of nutrition plane on productive performances of Ossimi ewes and their offspring during pregnancy and lactation periods.

\subsection{Experimental animals}

The experiment started at the beginning of the breeding season and lasted to the end of the lactation period. Twenty-four 
multiparous Ossimi ewes (second and third parity) aged 3-4 years and averaged $55.67 \mathrm{~kg}$ body weight. In last October 2017 the ewes were selected and weighted, then it were randomly assigned into three equal groups (8 of each) in a completely randomized design based on their body weight at the commencement of the study, ewes per group were kept together in one box (approximately $4 \times 5$ $\mathrm{m})$, and were fed groups. All ewes were synchronized with intravaginal progesterone pessaries and intramuscular injection of pregnant mare serum gonadotropin, Inta- vaginal sponges were inserted and left in place for 14 days. On the day of removal, the ewes were received an intramuscular injection of 300 IU of PMSG (PMSG, Syncropart. PMSG 600, Ceva, Sante Animale, Liboume, France). On the day of the second injection, the ewes were similarly divided into 3 equal groups ( 8 ewes each), all ewes were then run with fertile rams and the time to the onset of estrus or any subsequent heats was recorded, the ewes were then allowed to go to lambing. After four weeks of mating, the incidence of pregnancy was detected using Real-time ultrasound technique (Karen et al., 2009). The period from the beginning of the $2^{\text {nd }}$ month to the middle of the $4^{\text {th }}$ month of pregnancy was considered the mid- pregnancy and the next period to parturition was considered the latepregnancy. At the beginning of second month pregnant ewes were allocated to 1 of 3 nutritional treatments, $1^{\text {st }}$ group (G1) served as a control (ewes received the standard were obtained $100 \%$ ME of their maintenance energy requirements according to NRC (1985), $2^{\text {nd }}$ group (G2) ewes was fed a high energy diet (which received $125 \% \mathrm{ME}$ of $\mathrm{NRC}, 1985$ recommended allowances), and $3^{\text {rd }}$ group (G3) ewes was fed a low energy (which received $60 \% \mathrm{ME}$ of NRC,1985 recommended allowances). All ewes of these groups were fed $70 \%$ of their requirements as CFM and $30 \%$ from the roughage, roughage was offered ad libitum. Daily ration was divided into 2 equal parts and offered at 8.00 a.m. and 7.00 p.m. daily. Licks of vitaminsminerals and fresh water were available free of choice.

\subsection{Chemical analysis}

Feed ingredient samples were analyzed for dry matter, ash, crude protein, crud fiber and ether extract according to methods of AOAC (1995). The chemical composition of the ingredients are shown in Table (1).

Table (1): Ingredients and chemical composition of rations fed to ewes.

\begin{tabular}{lcc}
\hline Items & CFM & Wheat straw \\
\hline Dry matter (DM) \% & 92.98 & 90.63 \\
\hline Organic matter (OM)\% & 89.71 & 88.2 \\
\hline Crude protein (CP) \% & 16.43 & 3 \\
\hline Crude fiber(CF) \% & 09.15 & 39.33 \\
\hline Either extract (EE)\% & 4.64 & 1.73 \\
\hline Nitrogen free extract (NFE) \% & 59.49 & 44.13 \\
\hline Ash \% & 10.28 & 11.8 \\
\hline $\begin{array}{l}\text { CFM=Concentrate feed mixture, 1 kg CFM covered 100 \% the maintenance requirements of a ewe } \\
\text { weighing 60. }\end{array}$
\end{tabular}




\subsection{Productive traits}

Ewes were weighted monthly until parturition and after parturition till weaning. Weights of lambs were also recorded biweekly to weaning, net gain $(\mathrm{kg})$ and average daily gain (g) was calculated. The lambs were separated from their mother after birth, the colostrum yield was determined by hand milking and allowing lambs to suckle the residue of colostrum and calculating the differences between pre- and postsuckling weights of lambs, plus colostrum collected manually. Total colostrum produced during the first three days after parturition was recorded. At the beginning of the second week milk yield was recorded weekly, milk yield was measured by using lambs suckling technique (Ashmawy, 1980; Morsy, 2002).

\subsection{Blood sampling and analysis}

Blood samples were collected from the jugular vein from all ewes after 12 hours fasting. Blood samples were collected during gestation and then in days 30, 60 and 90 day after lambing. Blood samples were directly collected into clean dried glass culture tubes with EDTA (Ethylene Diamine Tetra Acetic Acid) as anticoagulant. The collected samples were centrifuged at $4000 \mathrm{rpm}$. for 15 minutes, subsequently blood plasma was separated into a clean dried glass vial and stored at $-24{ }^{\circ} \mathrm{C}$ for analysis. Collected plasma samples were analyzed by spectrophotometer, for total protein, according to Cannon (1974), albumin, according to Beng and Lim (1973), cholesterol according to Burtis et al. (2006). Triglycerides according to Scheletter and Nussel (1975) and glucose according to Howanitz and Howantiz (1984). Blood plasma globulin and albumin/globulin ratio (A/G) was obtained.

\subsection{Statistical Analysis}

The statistical analysis system (SAS, 2008) was used for mean of variance for separated measures of body weight, colostrum and milk yield, data of blood plasma analysis and lambs performance. The following model was applied:

$Y_{i j}=\mu+A_{i}+E_{i j}$

Where: $Y_{I J}=$ the studied trait, $\mu=$ the overall mean, $A_{i}=$ the effect of treatments $(i=1,2,3) . \quad E_{i j}=$ the experimental error, $\left(0, \sigma^{2}\right)$. Significant differences among means for each trait were detected using (Duncan, 1955).

\section{Results and Discussion}

\subsection{Live body weight of ewes}

The results in a Table (2) show that, average body weight of ewes offered high (G2) energy diet it was higher than the ewes that provided a $100 \%$ ME (G1) diet and $60 \% \mathrm{ME}(\mathrm{G} 3)$ of their requirements at pregnancy and lactation period. Plane of nutrition had not significant $(P \geq 0.05)$ effect on live body weight of ewes during pregnancy and lactation period. These results are in agreement with Muñoz et al. 
(2009), they reported that plane of nutrition had no significant effect on ewes live weight at lambing or weaning. Also, Aziz and Al-Dabbagh (2008) and Abdalla et al. (2012) found that plane of nutrition had no significant effect on ewes' weight at lambing and weaning. On the same line a study of Corner-Thomas et al. (2015) consistent with our results, they found that, live body weight of ewes allocated a 'Low', 'Intermediate' or 'High' feeding treatments did not differ during late pregnancy and lactation ewes or lamb performance from birth to weaning.

Table (2): Effect of nutrition plane on live body weight $(\mathrm{kg})$ of ewes during pregnancy and lactation period $($ Mean $\pm S E)$.

\begin{tabular}{|c|c|c|c|c|}
\hline \multirow{2}{*}{ Period } & \multicolumn{3}{|c|}{ Nutrition plane } & \multirow{2}{*}{ Sig } \\
\hline & G1 & $\mathrm{G} 2$ & G3 & \\
\hline \multicolumn{5}{|c|}{ During pregnancy } \\
\hline $2^{\text {nd }}$ month wt, $\mathrm{kg}$ & $59.38 \pm 4.92$ & $61.00 \pm 3.95$ & $59.38 \pm 4.92$ & ns \\
\hline $3^{\text {rd }}$ month wt, kg & $62.75 \pm 3.85$ & $64.25 \pm 3.98$ & $60.50 \pm 4.93$ & ns \\
\hline $4^{\text {th }}$ month wt, kg & $66.88 \pm 4.14$ & $68.25 \pm 3.62$ & $65.50 \pm 4.98$ & ns \\
\hline At lambing & $60.25 \pm 4.60$ & $63.38 \pm 3.25$ & $62.00 \pm 4.21$ & ns \\
\hline \multicolumn{5}{|c|}{ During lactation } \\
\hline $1^{\text {st }}$ month wt, kg & $60.14 \pm 4.45$ & $64.00 \pm 3.23$ & $57.83 \pm 4.81$ & ns \\
\hline $2^{\text {nd }}$ month wt, $\mathrm{kg}$ & $57.86 \pm 5.06$ & $61.14 \pm 2.82$ & $56.17 \pm 3.96$ & $\mathrm{~ns}$ \\
\hline $3^{\text {rd }}$ month wt, kg & $57.43 \pm 4.58$ & $60.14 \pm 2.57$ & $55.00 \pm 4.37$ & ns \\
\hline
\end{tabular}

\subsection{Colostrum and milk yield of ewes}

The effects of nutrition plane on colostrum yield after parturition are presented in Table (3). The results indicated that ewes offered high energy diet $(\mathrm{G} 2)$ had a significant $(P \leq 0.01)$ higher colostrum yield compared with both ewes offered intermediate (G1) or low energy (G3) diet. Increase in colostrum production may be attributed to mammary gland development. Mammary gland development takes place during the last month of pregnancy. In addition, the most remarkable development happens during a week before lambing the increased size of mammary gland leads to massive colostrum synthesis at the onset of milk production. Growth of the gland and mammary cell differentiation are both strongly influenced by nutrition of the ewe in late pregnancy (Nowak and Poindron, 2006; Robinson, 2002). In addition, a higher level of energy increases the plasma glucose concentration, which in turn requires the synthesis of lactose during the formation of colostrum. Thus, increasing the level of nutrition increases colostrum directly. The current results are in agreement with those of Hashemi et al., (2008) who found that ewes on the $110 \%$ NRC diet produced significantly $(P \leq 0.01)$ more 
colostrum than did those received $90 \%$ or $100 \%$ NRC diet. Also, Banchero et al. (2004b) found that Supplementation with cracked maize in the last 8 days of pregnancy increased colostrum production in both single- and twinbearing ewes. Banchero et al. (2004a) found that single- or twin-bearing ewes supplemented with $750 \mathrm{~g} / \mathrm{h} / \mathrm{d}$ during the last week of pregnancy produced $133 \%$ and $172 \%$ more colostrum than un supplemented ewes. McGovern et al., (2015a, 2015b) found that ewes offered diets lower than recommendation in both energy and protein in the last four weeks of gestation produced lower colostrum than recommendation. Effects of nutrition plane on total milk yield and average daily milk during the lactation period are presented in Table (3).

Table (3): Effect of nutrition plane on colostrum yield (g), total milk yield and average daily milk yield $(\mathrm{kg})$ of Ossimi ewes during lactation period (Mean $\pm \mathrm{SE})$.

\begin{tabular}{lccc}
\hline Treatments & Colostrum yield $(\mathrm{g})$ & Total milk yield $(\mathrm{kg})$ & Daily milk yield $(\mathrm{kg})$ \\
\hline $\mathrm{G} 1$ & $748.57 \pm 35.01^{\mathrm{b}}$ & $44.18 \pm 1.89^{\mathrm{b}}$ & $0.53 \pm 0.02^{\mathrm{b}}$ \\
\hline $\mathrm{G} 2$ & $1098.57 \pm 92.46^{\mathrm{a}}$ & $52.49 \pm 3.44^{\mathrm{a}}$ & $0.62 \pm 0.04^{\mathrm{a}}$ \\
\hline $\mathrm{G} 3$ & $671.67 \pm 68.87^{\mathrm{b}}$ & $36.61 \pm 2.60^{\mathrm{b}}$ & $0.44 \pm 0.03^{\mathrm{b}}$ \\
\hline Sig & $* *$ & $* *$ & $* *$ \\
\hline a,b,c means the same letter within columns are not significant $(P \geq 0.05) ., * *=$ probability $(\mathrm{P} \leq 0.01) . \mathrm{G} 1=$ group of \\
ewes were offered the standard of their maintenance energy requirements $(100 \%$ ME of $\mathrm{NRC}, 1985), \mathrm{G} 2=$ group of \\
ewes offered high energy (125\% ME of NRC, 1985 of their maintenance energy requirements), G3= group of ewes \\
offered low energy (60\% ME of NRC,1985 of their maintenance energy requirements).
\end{tabular}

The results indicated that ewes offered maintenance requirements (G1) or high energy (G2) diet significantly produced $(P \leq 0.01)$ total milk yield and average daily milk than those offered low energy diet (G3). In general ewes in G1 and G2 groups produced the greatest amount of milk during experimental period than ewes in G3 group. Data of weekly milk yield during lactation period (12 weeks) are presented in Table (4). Results showed that milk yield during $1^{\text {st }}$ month and $2^{\text {nd }}$ month of lactation were significantly $(P \leq 0.01)$ increased in ewes offered high $125 \% \mathrm{ME}$ and standard 100 $\% \mathrm{ME}$ compared with ewes offered low $60 \%$ ME diet. Milk yield of ewes from the $7^{\text {th }}$ weeks to the end of lactation were not significantly differed among all groups (Table 4). High milk production associated with a high diet may be due to the different effects of nutrition during pregnancy and lactation, or may by to the low development of their mammary gland during pregnancy, because the level of nutrition during pregnancy significantly affected the udder development, as was found in another article (Charismiadou et al., 2000). Our results are in agreement with those of Bizelis et al. (2000) found that daily milk yield during the first 3 weeks of lactation was significantly $(P \leq 0.05)$ affected by the level of nutrition during pregnancy. 
Many authors reported that milk parturition; Aziz and Al-Dabbagh (2008) production was affected by the on Hamdani ewes and Shams al-dain et nutritional plane before and after al.(2003) on Awassi ewes.

Table (4): Effect of nutrition plane on average weekly milk yield (kg) of Ossimi ewes during lactation period (Mean \pm SE).

\begin{tabular}{|c|c|c|c|c|c|}
\hline \multirow{2}{*}{\multicolumn{2}{|c|}{ Weeks of lactation }} & \multicolumn{3}{|c|}{ Nutrition plane } & \multirow{2}{*}{ Sig } \\
\hline & & G1 & G2 & G3 & \\
\hline \multirow{4}{*}{ Period 1} & 1 & $3.93 \pm 0.18^{b}$ & $4.84 \pm 0.45^{\mathrm{a}}$ & $3.01 \pm 0.11^{\mathrm{c}}$ & $* *$ \\
\hline & 2 & $4.16 \pm 0.20^{\mathrm{b}}$ & $5.49 \pm 0.50^{\mathrm{a}}$ & $3.61 \pm 0.25^{\mathrm{b}}$ & $* *$ \\
\hline & 3 & $4.93 \pm 0.30^{\mathrm{b}}$ & $6.35 \pm 0.60^{\mathrm{a}}$ & $3.64 \pm 0.33^{\mathrm{b}}$ & $* *$ \\
\hline & 4 & $5.37 \pm 0.39^{\mathrm{a}}$ & $6.03 \pm 0.32^{\mathrm{a}}$ & $3.64 \pm 0.24^{\mathrm{b}}$ & $* *$ \\
\hline \multicolumn{2}{|c|}{ Milk yield from (1 to 4 ) weeks } & $18.39 \pm 0.95^{\mathrm{b}}$ & $22.72 \pm 1.63^{\mathrm{a}}$ & $13.91 \pm 0.75^{\mathrm{c}}$ & $* *$ \\
\hline \multirow{4}{*}{ Period 2} & 5 & $5.22 \pm 0.33^{\mathrm{a}}$ & $5.60 \pm 0.40^{\mathrm{a}}$ & $3.97 \pm 0.35^{b}$ & $*$ \\
\hline & 6 & $4.38 \pm 0.29^{\mathrm{ab}}$ & $4.76 \pm 0.27^{\mathrm{a}}$ & $3.58 \pm 0.36^{\mathrm{b}}$ & $*$ \\
\hline & 7 & $3.72 \pm 0.36$ & $3.94 \pm 0.34$ & $3.17 \pm 0.33$ & ns \\
\hline & 8 & $3.17 \pm 0.24$ & $3.76 \pm 0.25$ & $2.90 \pm 0.36$ & ns \\
\hline \multicolumn{2}{|c|}{ Milk yield from (4 to 8) weeks } & $16.46 \pm 1.08^{\mathrm{ab}}$ & $18.06 \pm 1.02^{\mathrm{a}}$ & $13.64 \pm 1.29^{\mathrm{b}}$ & $*$ \\
\hline \multirow{4}{*}{ Period 3} & 9 & $2.80 \pm 0.33$ & $3.51 \pm 0.32$ & $2.61 \pm 0.25$ & ns \\
\hline & 10 & $2.40 \pm 0.18$ & $3.13 \pm 0.33$ & $2.41 \pm 0.21$ & ns \\
\hline & 11 & $2.20 \pm 0.18$ & $2.74 \pm 0.30$ & $2.18 \pm 0.18$ & ns \\
\hline & 12 & $1.90 \pm 0.19$ & $2.33 \pm 0.26$ & $1.85 \pm 0.15$ & $\mathrm{~ns}$ \\
\hline \multicolumn{2}{|c|}{ Milk yield from (9 to 12 ) weeks } & $9.30 \pm 0.82$ & $11.71 \pm 1.20$ & $9.06 \pm 0.77$ & $\mathrm{~ns}$ \\
\hline
\end{tabular}

\subsection{Blood constituents}

Effect of nutrition level on blood constituents are presented in Table (5). The current results indicated that total protein level in blood of pregnant ewes and during lactation $\left(1^{\text {st }}\right.$ month or $3^{\text {th }}$ month) did not significantly differ among treatment groups. In contrast during the $2^{\text {nd }}$ month of lactation ewes offered $125 \%$ ME or $100 \%$ ME diet had significantly higher $(P \leq 0.05)$ plasma total protein than those offered $60 \%$ ME diet. The albumin levels in the blood of the ewes during pregnancy and lactation are similar in all treatment groups. The results indicated that, there was a significant $(P \leq 0.05)$ decrease in the cholesterol concentrations in the blood plasma for G2 ewes during the late pregnancy stage and at 60 days of lactation (Table 5). Although, there were differences in cholesterol concentrations in blood plasma between G1, G2 and G3 groups at mid-pregnancy and at $1^{\text {st }}$ or $3^{\text {rd }}$ month of lactation, no significant differences were observed between them. No statistically significant differences in Triglycerides levels between G1, G2 and G3 ewes groups during pregnancy and lactation period. Plasma glucose level of 
ewes offered high $125 \% \mathrm{ME}$, and $100 \%$ ME diet were significantly higher than those offered low $60 \%$ ME diet during late pregnancy. No significantly differences were observed in glucose level among treatment groups during pregnancy and other lactation periods. The higher levels of plasma glucose in ewes received high energy in late pregnancy may be ascribed to; ruminants fed a forage diet have little glucose available for absorption (Bergman, 1974).

Table (5): Effect of nutrition plane on blood constituents of Ossimi ewes during gestation and lactation periods (Mean $\pm \mathrm{SE}$ ).

\begin{tabular}{|c|c|c|c|c|c|c|}
\hline & & \multicolumn{5}{|c|}{ Blood constituents } \\
\hline \multirow{2}{*}{\multicolumn{2}{|c|}{ Items }} & \multicolumn{2}{|c|}{ At pregnancy } & \multicolumn{3}{|c|}{ At lactation } \\
\hline & & Mid & Late & $1^{\text {st }}$ Month & $2^{\text {nd }}$ Month & $3^{\text {rd }}$ Month \\
\hline \multirow{3}{*}{ Total protein } & G1 & $5.71 \pm 0.31$ & $6.38 \pm 0.33$ & $5.45 \pm 0.31$ & $6.78 \pm 0.43^{\mathrm{a}}$ & $6.54 \pm 0.53$ \\
\hline & $\mathrm{G} 2$ & $5.87 \pm 0.27$ & $5.12 \pm 0.07$ & $5.60 \pm 0.22$ & $7.17 \pm 0.11^{\mathrm{a}}$ & $7.19 \pm 0.53$ \\
\hline & G3 & $5.87 \pm 0.35$ & $6.22 \pm 0.56$ & $5.88 \pm 0.32$ & $5.08 \pm 0.19^{b}$ & $6.51 \pm 0.18$ \\
\hline Sig & & ns & $\mathrm{ns}$ & ns & ns & ns \\
\hline \multirow{3}{*}{ Albumin } & G1 & $2.52 \pm 0.10$ & $2.45 \pm 0.15$ & $4.10 \pm 0.04$ & $4.09 \pm 0.17$ & $3.85 \pm 0.08$ \\
\hline & $\mathrm{G} 2$ & $2.71 \pm 0.07$ & $2.76 \pm 0.06$ & $4.00 \pm 0.10$ & $4.06 \pm 0.15$ & $3.99 \pm 0.25$ \\
\hline & G3 & $2.66 \pm 0.06$ & $2.76 \pm 0.07$ & $4.14 \pm 0.10$ & $3.94 \pm 0.19$ & $3.91 \pm 0.22$ \\
\hline Sig & & ns & $\mathrm{ns}$ & ns & ns & $\mathrm{ns}$ \\
\hline \multirow{3}{*}{ Cholesterol } & G1 & $195.7 \pm 10.70$ & $204 \pm 3.95^{\mathrm{a}}$ & $148.4 \pm 10.55$ & $166.4 \pm 8.91^{\mathrm{ab}}$ & $171.1 \pm 2.91$ \\
\hline & $\mathrm{G} 2$ & $187.9 \pm 8.33$ & $182.2 \pm 5.84^{\mathrm{b}}$ & $171.7 \pm 10.50$ & $160.6 \pm 8.66^{\mathrm{b}}$ & $167.7 \pm 3.74$ \\
\hline & G3 & $175 \pm 12.77$ & $209.7 \pm 5.14^{\mathrm{a}}$ & $158 \pm 5.66$ & $192.5 \pm 8.62^{\mathrm{a}}$ & $172.7 \pm 10.15$ \\
\hline Sig & & ns & $*$ & ns & $*$ & ns \\
\hline \multirow{3}{*}{ Triglycerides } & G1 & $144.5 \pm 9.97$ & $149 \pm 12.07$ & $216.9 \pm 11.51$ & $219.7 \pm 11.03$ & $218.8 \pm 18.32$ \\
\hline & $\mathrm{G} 2$ & $156.4 \pm 11.8$ & $137.8 \pm 11.53$ & $221.2 \pm 8.33$ & $224.3 \pm 16.02$ & $214.6 \pm 10.42$ \\
\hline & G3 & $151 \pm 9.36$ & $149.6 \pm 2.42$ & $211.4 \pm 7.49$ & $207.1 \pm 4.97$ & $219.3 \pm 14.12$ \\
\hline Sig & & ns & $\mathrm{ns}$ & $\mathrm{ns}$ & ns & ns \\
\hline \multirow{3}{*}{ Glucose } & G1 & $93.06 \pm 4.68$ & $100.9 \pm 0.55^{\mathrm{a}}$ & $104.9 \pm 6.21$ & $104.8 \pm 4.19$ & $102.5 \pm 6.54$ \\
\hline & G2 & $97.55 \pm 0.80$ & $102.3 \pm 3.47^{\mathrm{a}}$ & $98.76 \pm 5.88$ & $106.8 \pm 4.06$ & $108 \pm 7.05$ \\
\hline & G3 & $91.12 \pm 4.90$ & $93.54 \pm 1.62^{\mathrm{b}}$ & $100.3 \pm 6.44$ & $101.8 \pm 3.13$ & $100.4 \pm 3.41$ \\
\hline Sig & & ns & $*$ & $\mathrm{~ns}$ & ns & ns \\
\hline
\end{tabular}

These results are in agreement with those reported by Abd-Allah (2013) working on feeding different concentrates during the last two months pre-partum on ewe. Ewes were assigned to three treatments, ewes were fed on high energy ration (HE) ewes were fed on high protein ration (HP) and control. He found treatment affected albumin, $A / G$ ratio and glucose level significantly but the main differences cholesterol and triglyceride were insignificant. Serum albumin, total protein and urea levels were higher in the ewes fed HP. Mohammadi et al. (2016) studied that the energy related to the biochemical metabolites changes occurring during late pregnancy in Makouei breed sheep. They reported a 
decrease in albumin and total protein levels during pre-partum, values that kept decreasing after birth $(P \leq 0.05)$, also serum cholesterol and triglycerides were gradually decreased and reached low levels after lambing $(P \leq 0.05)$. Serum glucose concentrations were significantly lower at pre-partum period than postpartum $(P \leq 0.05)$. Chashnidel et al. (2018) found that the treatments with the high level of metabolizable energy were able significantly to avoid reducing energy carriers (glucose, cholesterol, triglycerides). Ólafsdóttir et al. (2012) found that glucose level was significantly affected by nutritional plane during late pregnancy. Moghaddam and Hassanpour (2008) showed that plasma glucose concentrations to be higher during lactation than pregnancy in sheep's. Bizelis et al. (2000) concluded that ewes whose energy intake was restricted during pregnancy, there was no significant carryover effect of level of nutrition in pregnancy on the biochemical parameters.
Wallace et al. (2005) found that maternal glucose concentrations were not affected overall by diet or stage of pregnancy.

\subsection{Performance of lambs}

The results in Table (6) show the change in the average body weight of lambs during suckling period. The results showed a significant difference $(\mathrm{P} \leq 0.05)$ in birth weight according to the level of nutrition. The highest birth weight was found with lambs resulting from ewes being served a high energy nutritional level $(125 \% \mathrm{ME})$ followed by ewes providing a standard energy (100\%ME) diet and ewes offering a low energy $(60 \% \mathrm{ME})$ diet. In this study, maternal energy intake from mid to late pregnancy had a significant effect on the birth weight, mid and late pregnancy intake was positively correlated with birth weight in the term, and it is not surprising that the absolute fetal growth was greater at this time.

Table (6): Effect of nutrition plane on live body weight, total gain $(\mathrm{kg})$ and average daily gain $(\mathrm{g})$ of lambs.

\begin{tabular}{lcccc}
\hline Items & G1 & G2 & G3 & Sig \\
\hline Birth weight $(\mathrm{kg})$ & $3.75 \pm 0.27^{\mathrm{b}}$ & $4.86 \pm 0.18^{\mathrm{a}}$ & $3.69 \pm 0.31^{\mathrm{b}}$ & $*$ \\
\hline Weaning weight $(\mathrm{kg})$ & $18.93 \pm 0.52^{\mathrm{ab}}$ & $20.07 \pm 1.66^{\mathrm{a}}$ & $15.48 \pm 1.39^{\mathrm{b}}$ & $* *$ \\
\hline Total gain $(\mathrm{kg})$ & $14.87 \pm 0.40^{\mathrm{ab}}$ & $15.21 \pm 1.61^{\mathrm{a}}$ & $11.65 \pm 1.25^{\mathrm{b}}$ & $* *$ \\
\hline Average daily gain $(\mathrm{g})$ & $165.3 \pm 4.45^{\mathrm{ab}}$ & $169 \pm 17.84^{\mathrm{a}}$ & $129.5 \pm 13.91^{\mathrm{b}}$ & $*$ \\
\hline a,b,c means the same letter within columns are not significant $(P \leq 0.05), * *=$ probability $(\mathrm{P} \leq 0.01) . \mathrm{G} 1=$ group of \\
ewes were offered their maintenance requirements from energy $(100 \% \mathrm{ME})$ diet, $\mathrm{G} 2=$ group of ewes offered \\
high energy (125\% ME) diet, G3= group of ewes offered low energy $(60 \% \mathrm{ME})$ diet.
\end{tabular}

Consequently, it appears that the state of the mother's body before pregnancy and energy intake in late pregnancy are most important in terms of birth weight in sheep. Based on current data, we also agree with Gardner et al. (2007) he reported that energy intake during gestation had a significant $(\mathrm{P} \leq 0.001)$ influence on weight at birth of sheep. Demirel et al. (2000) found that average 
lamb birth weights were $3.97,4.15,4.02$ and $4.5 \mathrm{Kg}$ for ewes fed $80,100,115$ and $130 \%$ of NRC allowances during late pregnancy, respectively. They reported that the $4^{\text {th }}$ group had significantly higher birth weight than the other groups. AbdAllah (2013) found that feeding high energy $\mathrm{HE}$ to ewes during late gestation increased $(P \leq 0.05)$ birth weights of their lambs. Highly significant increase $(P \leq 0.01)$ were observed in weaning weight of lambs resulting from ewes provided with high-energy (125\% ME) diet compared with lambs in standard (100\% ME) and low (60\% ME) plane of nutrition. Also, Results indicated that total gain of lambs born from G2 ewes was highly significant increase $(P \leq 0.01)$ from birth to weaning as compared with lambs born from G1 and G3 ewes. These results are in agreement with those reported by Abd El-Gawad (2002) found that highly significant effect $(P \leq 0.01)$ of dams feeding levels during early lactation period on weaning weight. He indicated that total gain was higher with high level of feeding compared to in the standard feed level. Corner-Thomas et al. (2015) reported that feeding treatments on lamb live weight at weaning, lambs born to the high treatment were heavier than the intermediate treatment, which were heavier than the low treatment.

\section{Conclusions}

From these results it can be concluded that, (100\% ME) NRC, 1985 allowances is reasonably covering the feed requirement of ewes especially in the critical production stages, pregnancy and lactation, and that $125 \% \mathrm{ME}$ of the feed allowances only caused slight improvement in milk yield. Therefore, improving ewe nutrition in the late gestational period improves both colostrum and milk yield while minimally affecting ewe and lamb performance. However, applying a low 60\% ME to ewes during pregnancy and lactation period negatively impacted ewe milk production, which potentially can lead to compromised lamb growth.

\section{References}

Abd El-Gawad, A. G. M. (2002), Effect of feeding levels on reproductive and productive performance of Egyptian Nubian goats, Ph.D. Thesis, Faculty of Agriculture, Mansoura University, Mansoura, Egypt.

Abdalla, E. B., Ammou, F. A., El-Shafie, M. H., El-Bordeny, N. E. and Hamida, R. M. (2012), "Effect of feeding levels on the productive performance of Barki sheep", Egyptian Journal of Sheep and Goat Science, Vol. 7, pp. 11-15.

Abd-Allah, M. (2013), "Effects of parity and nutrition plane during late pregnancy on metabolic responses, colostrum production and lamb output of Rahmani ewes", Egyptian Journal of Animal Production, Vol. 50 No. 3, pp. 132-142.

Addah, W. and Karikari, P. K. (2008), 
"Effects of dietary restrictions during different stages of pregnancy on differential plasma protein concentration, placental and birth weights of adolescent Djallonké sheep", Livestock Research for Rural Development, Vol. 20 No. 9, Article \#138.

Ashmawy, B. M. (1980), "Comparison of three techniques for estimation of the milk Production of small ruminants". Egyptian Journal of Animal Production, Vol. 20 No. 1, pp. 11-19.

Aziz, K. O. and Al-Dabbagh, A. S. S. (2008), "Effect of plane of nutrition during late pregnancy and early lactation on milk production and lambs growth of Hamadni ewes", Jordan Journal of Agriculture Science, Vol. 4 No. 2, pp. 148-15.

Banchero, G. E., Quintans, G., Martin, G. B., Lindsay, D. R. and Milton, J. T. B. (2004a), "Nutrition and colostrum production in sheep. 1. Metabolic and hormonal responses to a highenergy supplement in the final stages of pregnancy", Reproduction, Fertility and Development, Vol. 16 No. 6, pp. 633-643.

Banchero, G. E., Quintans, G., Martin, G. B., Lindsay, D. R. and Milton, J. T. B.(2004b), "Nutrition and colostrum production in sheep. 2. Metabolic and hormonal responses to different energy sources in the final stages of pregnancy", Reproduction, Fertility and Development, Vol. 16 No. 6, pp.
645-653.

Behrendt, R., van Burgel, A. J., Bailey, A., Barber, P., Curnow, M., Gordon, D. J. and Thompson, A. N. (2011), "On-farm paddock-scale comparesons across southern Australia confirm that increasing the nutrition of Merino ewes improves their production and the lifetime performance of their progeny", Animal Production Science, Vol. 51 No. 9, pp. 805-812

Beng, C. G. and Lim, K. L. (1973), "Colorimetric determination of albumin in serum", American Journal of Clinical Pathology, Vol. 59, pp. 14-21.

Bergman, E. N. (1974), "Glucose metabolism: comparison of wholebody turnover with production by gut, liver and kidneys", Federation Proceedings, Vol. 33, pp. 1849 1854.

Binns, S. H., Cox, I. J., Rizvi, S. and Green, L. E. (2002), "Risk factors for lamb mortality on UK sheep farms", Preventive Veterinary Medicine, Vol. 52, No.3-4, pp. 287303.

Bizelis, J.A., Charismiadou, M.A., and Rodkais, E. (2000), "Metabolic changes during the perinatal period in dairy sheep in relation to level of nutrition and breed. II. Early lactation", Journal of Animal Physiology and Animal Nutrition, Vol. 84 No. 3-4, pp.73-84. 
Blair, H. T., Jenkinson, C. M. C., Peterson, S. W., Kenyon, P. R. V., Van der Linden, D. S., Davenport, L. C., Mackenzie, D. D., Morris, S. T. and Firth, E. C. (2010), "Dam and grand dam feeding during pregnancy in sheep affects milk supply in offspring and reproductive performance in grand-offspring". Animal Science Journal, Vol. 88 No. 13, pp. 2523-2527.

Burtis, C. A., Ashwood, E. R. and Bruns, D. E. (2006), Tietz Textbook of Clinical Chemistry and Molecular Diagnostics, $4^{\text {th }}$ Ed., Elsevier Saunders, St. Louis., pp. 942-956.

Cannon, D. C. (1974), "Examination of seminal fluid", Proceedings of the Royal Society of Medicine, Vol. 31, pp. 1201-1207.

Charismiadou, M. A., Bizelis, J. A. and Rogdakis, E. (2000), "Metabolic changes during the perinatal period in dairy sheep in relation to level of nutrition and breed. I. Late pregnancy", Journal of Animal Physiology and Animal Nutrition, Vol. 84 No. 3-4, pp. 61-72.

Chashnidel, Y., Teimouri Yansari, A. and Dirandeh, E. (2018), "Effects of increasing level of metabolizable energy and protein on feed intake, nutrient digestibility, performance and blood metabolites of Zell pregnant ewes at late gestation", Research on Animal Production (Scientific and Research), Vol. 9 No. 22, pp. 60-71.
Coop, I. E., Clark, V. R. and Claro, D. (1972),"Nutrition of the ewe in early lactation: I. lamb growth rate", New Zealand Journal of Agricultural Research, Vol. 15 No. 2, pp. 203208.

Corner-Thomas, R. A., Hickson, R. E., Morris, S. T., Back, P. J., Ridler, A. L., Stafford, K. J. and Kenyon, P. R. (2015), "Effects of body condition score and nutrition in lactation on twin-bearing ewe and lamb performance to weaning", New Zealand journal of agricultural research, Vol. 58 No. 2, pp. 156169.

Demirel, M., Aygun, T., Altin, T. and Bingol, M. (2000), "The effect of different levels of feeding in late gestation on ewe weight, lamb birth weight and lamb growth of Karakas and Hamdani ewes", Turkish Journal of Veterinary and Animal Sciences, Vol. 24 No. 3, pp. 243 249.

Duncan, D. B. (1955), "Multiple range and multiple F tests", Biometrics, Vol. 11 No. 1, pp. 1-42.

Gardner, D. S., Buttery, P. J., Daniel, Z. and Symonds, M. E. (2007), "Factors affecting birth weight in sheep: maternal environment", Reproduction, Vol. 133 No. 1, pp. 297-307.

Greenwood, P. L., Thompson, A. N. and Ford, S. P. (2010), "Postnatal consequences of the maternal 
environment and of growth during prenatal life for productivity of ruminants", Managing the prenatal environment to enhance livestock productivity, Springer, Dordrecht, pp. 3-36.

Hashemi, M., Zamiri, M. J., and Safdarian, M. (2008), "Effects of nutritional level during late pregnancy on colostral production and blood immunoglobulin levels of Karakul ewes and their lambs", Small Ruminant Research, Vol. 75 No. 2-3, pp. 204-209.

Howanitz, P. J. and Howantiz, J. H. (1984), Clinical Diagnosis and Management b) Laboratory Methods, $17^{\text {th }}$ Ed., Henry J. B. (Ed.), W.B. Saunders, Philadelphia, pp. 168.

Karen, A. M, El-Sayed, M. F. and AbuZeid, S. S. (2009), "Estimation of gestational age in Egyptian native goats by ultrasonographic fetometry", Animal Reproduction Science, Vol. 114 No. 1-3, pp. 167174.

Kenyon, P. R., Morel, P. C. H., Perkins, N. R. and West, D. M. (2004), "Effect of ewe live weight and condition score at mating, and midpregnancy shearing, on birth weights and growth rates of twin lambs to weaning", New Zealand Veterinary Journal, Vol. 52, 145-149.

McGovern, F. M., Campion, F. P., Lott, S. and Boland, T. M. (2015a),
"Altering ewe nutrition in late gestation: I. The impact on pre-and postpartum ewe performance", Journal of Animal Science, Vol. 93 No. 10, pp. 4860-4872.

McGovern, F. M., Campion, F. P., Sweeney, T., Fair, S., Lott, S. and Boland, T. M. (2015b), "Altering ewe nutrition in late gestation: II. The impact on fetal development and offspring performance", Journal of Animal Science, Vol. 93 No. 10, pp. 4873-4882.

Moghaddam, G. and Hassanpour, A. (2008), "Comparison of blood serum glucose, beta hydroxybutyric acid, blood urea nitrogen and calcium concentrations in pregnant and lambed ewes", Journal of Animal Veterinary Advances, Vol. 7 No. 3, pp. 308-311.

Mohammadi, V., Anassori, E. and Jafari, S. (2016), Measure of energy related biochemical metabolites changes during peri-partum period in Makouei breed sheep, Veterinary Research Forum, Faculty of Veterinary Medicine, Urmia University, Urmia, Iran, Vol. 7 No. 1, p. 35 ,

Morand-Fehr, P. and Doreau, M. (2001), "Ingestion et digestion chez les ruminants soumis à un stress de chaleur", Productions Animales, Vol. 1 No. 14, pp. 15-27.

Morgan, J. E., Fogarty, N. M., Nielsen, S. and Gilmour, A. R. (2007), "The 
relationship of lamb growth from birth to weaning and the milk production of their primiparous crossbred dams", Australian Journal of Experimental Agriculture, Vol. 47 No. 8, pp. 899-904.

Morsy, A. H. A. (2002), Evaluation of prolific and non-prolific breeds of sheep under the environmental condition of middle Egypt, Ph.D. Thesis, Faculty of Agriculture, Minia University, Minia, Egypt.

Muñoz, C., Carson, A. F., McCoy, M. A., Dawson, L. E. R., Wylie, A. R. G. and Gordon, A. W. (2009), "Effects of plane of nutrition of ewes in early and mid-pregnancy on performance of the offspring: female reproduction and male carcass characteristics", Journal of Animal Science, Vol. 87 No. 11, pp. 36473655 .

Nowak, R. and Poindron, P. (2006), "From birth to colostrum: early steps leading to lamb survival", Reproduction Nutrition Development, Vol. 46 No. 4, pp. 431-446.

NRC, National Research Council (1985), Nutrient Requirements of Sheep, $6^{\text {th }}$ Ed., National Research Council, Washington, DC., USA.

Ólafsdóttir, H. Ó., Sveinbjörnsson, J. and Harðarson, G. H. (2012), Energy and protein in the diet of ewes in late pregnancy: Effect on ewe feed intake, life weight, body condition and concentration of plasma metabolites, M.Sc Thesis, Agricultural University of Iceland, Borgarnes, Iceland.

Redmer, D. A., Wallace, J. M. and Reynolds, L. P. (2004), "Effect of nutrient intake during pregnancy on fetal and placental growth and vascular development", Domestic Animal Endocrinology, Vol. 27 No. 3, pp. 199-217.

Robinson, J. J. (2002), Review of nutritional standards for sheep, British Society of Animal Science Annual Conference, York, England

SAS (2008), SAS Institute, Inc. Cary, $\mathrm{NC}$, USA.

Scheletter, G. and Nussel, E. (1975), "Arbeitsmed", Sozialmed Pracentimed, Vol. 10, pp. 25.

Shams al-dain., Qusay Z., Al-Rawi, E. A. and Ayoub, K. A. (2003), "Effect of using different nutrition levels on feeding pregnant Awassi ewes as affected in lamb growth, milk production and chemical composition", Tikrit Journal for Agricultural Sciences, Vol. 3 No. 7, pp. $48-60$.

Wallace, J. M., Milne, J. S. and Aitken, R. P. (2005), "The effect of over nourishing singleton-bearing adult ewes on nutrient partitioning to the gravid uterus", British Journal of Nutrition, Vol. 94 No. 4, pp. 533539. 